\title{
Photovoice Activities to Teach Writing for High School Students
}

\section{Enti Khoirun Nisa}

Islamic University of Indonesia

Email Correspondence: 17322093@ students.uii.ac.id

\begin{abstract}
Photovoice is reflective learning that engages learners' writing ability by having their literature from their experiences into perspective through photography. It is reflected in what happened, what has been done, or what is happening. The central premise of the study is that students have difficulty expressing their perspectives and creativity in literature. They are unable to brainstorm successfully in an online classroom because of individual factors. Photovoice is a relevant tool to engage students' motivation and writing ability since the photovoice role as guidance to write literature review by gathering ideas by their perspective and reflecting their voice to divide with others. Thus, this study aims to report that investigated photovoice activity to teach writing to high school students. The research was conducted in one of the Senior High schools in Yogyakarta. The data collected through photovoice and analyzed by using SHOWeD Analysis (1) what do you see here; (2) What is happening; (3) how does this relate to our lives; (4) why are things this way; (5) how could this image educate people?
\end{abstract}

Keywords: photovoice; writing skills; online learning

$$
\text { DOI }
$$

: https://doi.org/10.24903/bej.v3i1.706

\begin{tabular}{|l|l|l|}
\hline Received & $:$ & January 2021 \\
\hline Accepted & $:$ & January 2021 \\
\hline Published & $:$ & February 2021 \\
\hline $\begin{array}{l}\text { Copyright and } \\
\text { License }\end{array}$ & $\begin{array}{l}\text { Authors retain copyright and grant the journal the right of first publication with } \\
\text { the work simultaneously licensed under a Creative Commons Attribution 4.0 }\end{array}$ \\
\hline & $:$ & $\begin{array}{l}\text { International License that allows others to share the work with an acknowledgment of } \\
\text { the work's authorship and initial publication in this journal. }\end{array}$ \\
\hline
\end{tabular}




\section{INTRODUCTION}

As the demand for world life skill, English becomes the main key factor to surviving in modernity. Apart from it, due to the importance of English as a communicator to communicate with others, it is important for people to learn English from the beginning to advanced learning. Current studies on the photo-voice activity in writing projects drawing some issues related to individual perspectives and second language writing.

Based on my observation, a common problem in online teaching activities during the pandemic is when the teacher gives material and starts the discussion about a topic, few students have difficulty in expressing their point of view about it. A partial gaped was found during my internship program. The students had difficulties expressing their perspectives and understanding on how the teacher explains the material. Since the students had lack of attention and the teacher has not built activity that motivated students in online learning because the teacher had individual issues, the students' less active in online learning. I had observed how the class activity was conducted during online learning. The teacher used WhatsApp group as their two-way communication to explain and discuss the material, then used google classroom only to submit group assignments. Rarely, the teacher uses various teaching methods to motivate the students. Therefore, when I practiced teaching English language, I tried to put social media as their contribution to work achievement to give them a new atmosphere in learning material. Their response was unpredictable; they were so excited using social media to submit the assignment because they felt like there was no pressure through the assignment.

In addition, I teach caption as a topic to teach writing skills towards social media to express the way students' ability to identify, represent, and enhance their community to specific photographs. Since the students are $\mathrm{Z}$ generation, it will help them easier to learn English language as a base with technology.

Photo-voice is a research method that was developed by Caroline Wang and Marry Ann Burris in 1992. Photo-voice is a photographic technique that facilitates people to act as visual recorders based on their perspective and experience. According to Wang (1997), photo-voice has three main goals; (1) to permit people to record and reflect their concern, (2) to elevate critical understanding about the important issue through small and large group discussion of a photograph, (3) to reach policymakers. Thus, photo-voice helps people to analyze and explore things deeper. 
According to Drajati, Ngadiso, and Zainnuri (2019), photo-voice is participatory action research using photos and pictures to give the chance of having self-reflection about the process of teaching, learning, and sharing their knowledge and experience to others. Those stages of activity start from taking a picture, analyzing the critical idea, and solving the problem. Photo-voice as self-reflective is related to writing projects. As well as Adams \& brooks (2014) said that photo-voice can provide an instructional approach that helps students to analyze the issues that impact their lives, questioning structures, and improve their beliefs through their perspective. People's experiences influence how students gather an idea into a sentence. Students with a higher level of intelligence may reveal a commitment to how they write according to prior knowledge and make a massive effort by giving comprehensive understanding such as summarizing and synthesizing discussion points. While students with low levels might show little effort in what they write such as general knowledge and may post a similar message of the content.

Writing skills are one of the important skills that must be expertise by the students. Those steps are about how people gather ideas into several sentences that have a meaning or draw some issue. According to Hyland (2004), the writing process has a specific purpose and personal experience of the writer. Furthermore, Nunan (2003) stated that the writing process indicates the act of gathering the idea until they are presented and understandable to the readers. Westwood (2008) stated that there are two main approaches regarding teaching writing, there are process approaches and the skill-based approach. The process approach is about the learning process on how students become a creator. This approach focuses on the content and message of the idea rather than the grammatical aspect. The skill-based approach tends to focus on the teacher as the center of the learning process. The skill-based approach affirms the structural content to reflect grammatical error, well-organized content.

Photography is one of the various methods of the teaching process in writing skills. The researcher believes that a photograph can help the students to stimulate the inspiration to write an issue and gather ideas. According to Sharon E, Robert, \& James D (2004) visual stimulation strongly influence creating ideas. Bringing a lot of references and imagination on what to write, and how to write. In this research, the researcher used SHOWeD Analysis by Wang and Burris (1997). SHOWeD is the section of question that students answer as they analyze their photo:

$\mathrm{S} \quad=$ What do you See here?

$\mathrm{H} \quad=$ What is really Happening here? 
$\mathrm{O}=$ How does this relate to Our lives for your life personally?

$\mathrm{W} \quad=$ Why does this situation, concern or strength exist?

e $\quad=$ how could this image Educate the community (class)?

D = What can we Do about it?

Those six questions to the SHOWeD analysis help students to frame narrative and critical answers. It will guide them exploring things and share their perspective in selfreflection.

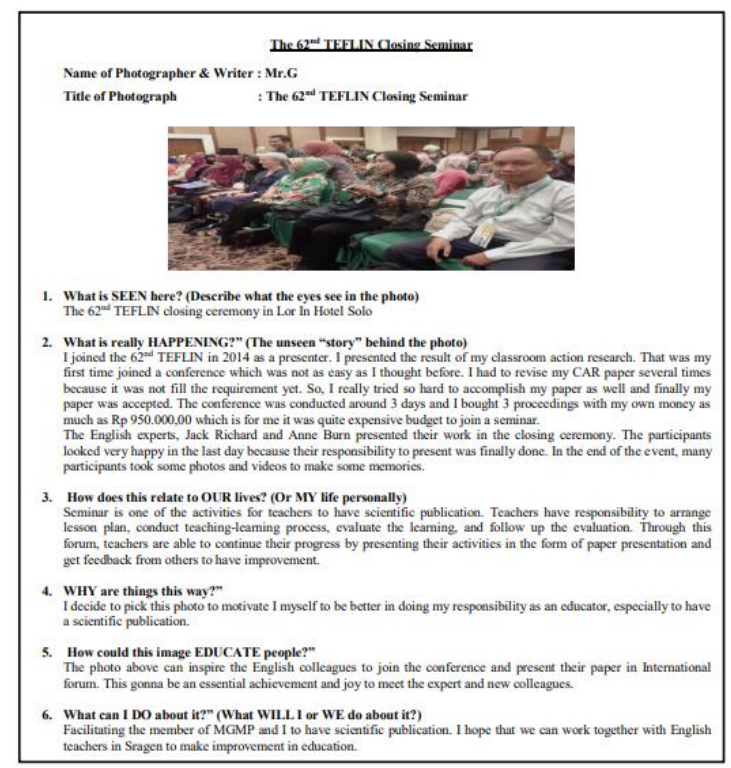

Figure 2.1 the example article of photo-voice

Thus, it will help the students to develop their idea by using photographs rather than teacher instruction.

\section{METHODOLOGY}

This study applied self-observational study, adapted from Showed Analysis by Wang and Burris 1997. This paper investigated photovoice activities conducted to teach writing skills. The qualitative data was used by the researcher to observe a teaching experience as primary data.

\subsection{Setting and Participant}

The setting of this study was conducted in one of favorite senior high schools in Yogyakarta. The schools are located in Prambanan, Yogyakarta, Indonesia. 32 students participated. a writing project can be used as a final result of student performance in an online learning process. 


\subsection{Data Collection}

The data were collected through students' assignments and activities. The assignments were analyzing the photo using SHOWeD Analysis. Firstly, what they have to do is discuss with the teacher about "writing caption", then after they understand the material they have to choose one topic to write a caption. After that, the teacher asks students to discuss with their peer friends to brainstorm and share an idea of each other. The last step is they write down a caption based on their topic and photo analysis. The data collected by students' handwriting paragraph is marked by their detailed information and also their imaginative idea.

\subsection{Self-observational Study}

Self-observational studies help the researchers to understand deeper about the characteristics of participants. Self-observation conducted to maintain, control, and monitor the learning process, and also to understand behavior change and students' characteristics. This helps pre-service teachers to understand that photovoice activities can be taught to high school students in writing projects.

\subsection{Research Porcedure and Data Analysis}

In this research, the researcher conducted need analysis regarding students activities.

Table 2.4.1 Data Collection Procedure

\begin{tabular}{|c|c|c|c|}
\hline Stages & Setting & Participant & Data Collection \\
\hline $\begin{array}{l}\text { Writing } \\
\text { (Production and } \\
\text { Practice) }\end{array}$ & $\begin{array}{l}\text { The pre-service } \\
\text { teacher explains } \\
\text { about writing } \\
\text { caption, then the } \\
\text { teacher asks to } \\
\text { write a detailed } \\
\text { information } \\
\text { regarding } \\
\text { SHOWeD } \\
\text { Analysis. }\end{array}$ & $\begin{array}{l}32 \text { students } \\
\text { participated in } \\
\text { writing projects. }\end{array}$ & $\begin{array}{l}\text { The result is the } \\
\text { students' } \\
\text { handwriting with } \\
\text { detailed } \\
\text { information. }\end{array}$ \\
\hline
\end{tabular}




\section{FINDINGS}

The observational study was guided by SHOWeD analysis by Wang and Burris (1997). Writing analysis has shown that 32 students participated made a diverse idea in expressing point of view. According to Wang and Burris (1997) photovoice provide a perspective of "problem-posing education" that grant participant to define an ussue and framing an action. Photovoice can be use as a method to explain, inform, and organize to focuss on their concern, discussing problem, and finding a solution. The students with a photo can transcript setting and interaction. It helps them to bring the explanations, ideas, or perspectives towards language learning process.

Marquez Zenkov and Harmon (2017) said that students in young age proficient with visual text, including photographic images. It helps them to boosting their literacy activity with relevant methode. The photo evaluation providing students perspective based on their schooling and life experience.

\section{DISCUSSION}

\subsection{Photovoice as self-reflection with SHOWeD analysis}

The participants feel comfortable using photo-voice with SHOWeD analysis for the first time. Based on their point of view, the topic is interesting since the method of data collection combined with social media. The role of social media influences their final result of learning projects. The students said that this time was contrasting compared to other years because due to covid-19 impacting all sectors including the education sector, the method that they used to learn changed into online class, and the class was so boring because there is no innovation towards the learning method. By learning photovoice as self-reflection students feel free to express the way they feel about topics and expressing different points of view.

It can be an interesting method for students to write their expressions based on the pictures and their experiences. SHOWeD analysis helps them as guidance to write what they must write. It has developed the awareness of students' needs for the teacher, not only about the quality of the material but also the quality of students' needs. The learning process can be evaluated using summative evaluation by methods such as self-evaluation and analysis of the product. The indicator of evaluation can be described with the way students addressed the problem by analysing the idea and the content information and the decision makers have been informed about the problem. The participants study in senior 
high school in Yogyakarta, Indonesia. The students took photos/pictures based on their interest or their personal life. The researcher did the SHOWeD analysis of the picture as self-reflection from the students.

During the implementation, I made the activities into the stages below:

\subsubsection{Discussing with te teacher about caption and writing caption}

During my internship program, I used Google classroom to communicate with the students as my GPL suggested to me. It helps them to minimize the consumption of internet data. In this stage I used SHOWeD analysis and self-reflectiveness. The teacher explained about writing caption and how to use caption. At this point I use 2 kinds of media, video explanation and powerpoint. It helps them to learn repeatable by remote learning, so everyone can clearly understand the material. The students can easily understand the material because there are video explanations combined with powerpoint which means they can learn remotely anywhere and repeatedly.

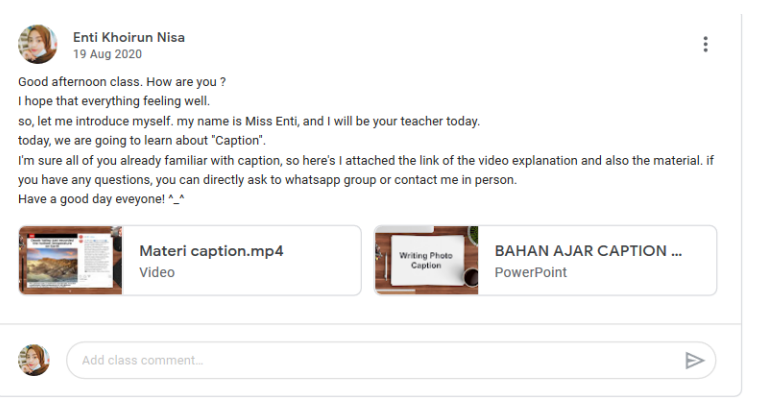

Figure 4.1 The Discussing Point

\subsubsection{Select a topic to write a caption}

The topic may vary, as long as it is appropriate and depends on the students' needs. The reason why I ask them to pick their theme is that I don't want to limit their creativity and their ideas on how they see things. So, the students can be fully creative and combine an idea based on their experience and perspective. The respondents picked a photo under the theme of online learning because she wants to express the interesting point about online class in self-reflection. Since the covid-19 influence online learning, she wants to voice up what she thinks about online learning, is it already effective for either student or teacher.

\subsubsection{Students are asked to take their photos based on their topic}

Students may use their camera for taking photos. They are allowed to take photos inside or outside the classroom. Students can take photos from daily activities or photos 
they might think have values or meaning. In these stages, it helps them to find the reference and the imagination about the content and the ideas.

Upload 1 image to your social media account using photo caption then, please screen-shoot and

send it directly to this google form!

^. Add File

Figure 4.2 Students' Task

\subsubsection{Students analyze the photo}

After the students take a few photos, they have to choose the best one to represent their voice and their interest. Students are asked to analyse the photo using SHOWeD analysis. The students should choose the best photo to narrate their idea. The narration is based on the question using SHOWeD analysis.

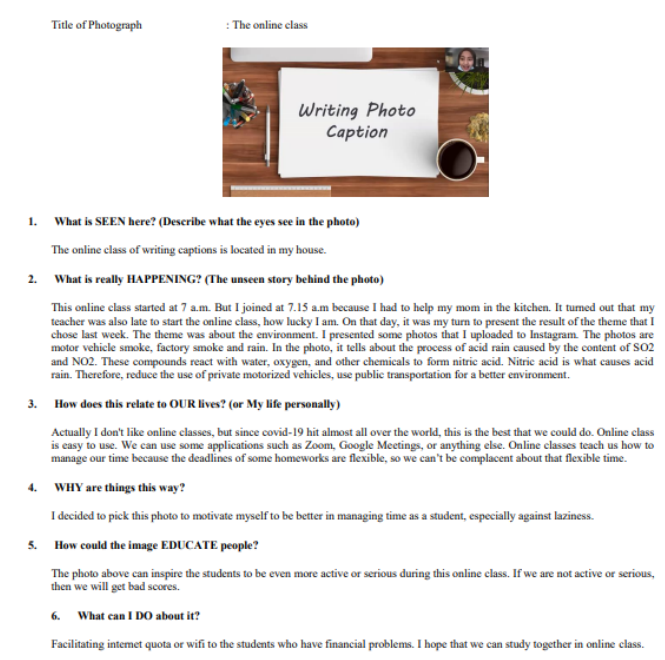

Figure 3.3 Students' Portfolio

Based on the data above, by providing a photovoice activities in writing project, it is very essential for students to learn specialist skills about writing context. When the teacher asks them to re-tell a story based on what happened on the photo. Photovoice can be an effective way of teaching English because it helps them to find the reference and the imagination about the content and the ideas. By understanding SHOWeD analysis, students can explain in detailed information by visual stimulation the students can creating a good idea, bringing a lot of references and imagination on what to write, and how to write.

It can be concluded that, photovoice activities are teaching method that have strongly influence in student's performance both critical thinking and writing skills. Writing skill is important to students because as a student they must have four basic education skills, 
writing, speaking, reading, and listening. The way photovoice bring such inspiration to students to write, it is usefull for them to expecting and creating new imagination and bringing such a good idea in writing projects.

\section{CONCLUSION}

From the activity that I implemented during my internship program, photo-voice is a useful instrument for the teacher to know and implement self-reflection in writing projects. Photo-voice combined with technology can be effective as students' motivation to learn beyond the classroom. The photograph can help the students to stimulate the inspiration or idea to write an issue and gather into literature. Nowadays, the innovation of educational tools by knowing multimodal literacy such as picture, gestures, and other visual knowledge can help teachers and students develop themselves into some professional and expertise skills.

Photo-voice is one of the multimodal literacies that can help both students and teachers. It can be a tool to act by self-reflection. students may use their facilities such as mobile phones and other technologies to support their capability in writing projects. It enriches the source, inspiration, and other knowledge to gather into a journal.

\section{REFERENCE}

[1] Adams, S. R. (2014). Digital Commons @ Butler University Using PhotoVoice to empower K-12 teachers and students through authentic literacy engagements.

[2] Drajati, N. A., Ngadiso, N., \& Zainnuri, H. (2020). Promoting Photovoice for Teachers' Self-Reflection on Multimodal Literacy. Al-Ta Lim Journal, 26(3), 309-317. https://doi.org/10.15548/jt.v26i3.513

[3] Hyland, K. (2004).Genre and second language writing. Ann Arbor, MI: The University of Michigan Press.

[4] Marquez-Zenkov, K., \& Harmon, J.A. (2007). "Seeing" English in the city: Using photography to understand students' literacy relationships. English Journal, 96(6), 2430.

[5] Nunan, D. (2003) Practical English Language Teaching. International Edition, McGrawHill, Singapore, 88. 
[6] Smaldino, Sharon, James D. Russel, Robert Heinich, Michael Molenda, 2005, Instructional Technology and Media for Learning, Pearson Merrill Prentice Hall. Upper Saddle river. Ohio: New Jersey colomcus

[7] Wang, C., \& Burris, M. A. (1997). Photovoice: Concept, Methodology, and Use for Participatory Needs Assessment. Health Education and Behavior, 24(3), 369-387. https://doi.org/10.1177/109019819702400309

[8] Westwood, P. (2008). What teachers need to know about teaching methods. Camberwell, Vic: ACER Press. 